\title{
Histochemical Studies in Exocrine and Endocrine Part of Pancreas in Chabero Chicken
}

\author{
Renu Yadav', Ajay Prakash', M.M. Farooqui ${ }^{1}$, Archana Pathak ${ }^{2}$ and Amit Vishen ${ }^{2}$ \\ ${ }^{1}$ Department of Veterinary Anatomy, College of Veterinary and Animal Sciences, U.P., India \\ ${ }^{2}$ Pandit Deen Dayal Upadhyaya Pashu Chikitsa Vigyan Vishwavidyalaya Evam Go- \\ Anusandhan Sansthan, (DUVASU), Mathura - 281001, Uttar Pradesh, India \\ *Corresponding author
}

\section{A B S T R A C T}

\begin{tabular}{|l|}
\hline Ke y w o r d s \\
Chabero Chicken, \\
Histochemical \\
Studies
\end{tabular}

Histochemical studies were conducted on the pancreas of twenty four apparently healthy chabro chickens irrespective of sex. The birds were divided into four age groups i.e. Group- 1, Group- 2, Group- 3 and Group- 4. The reaction for PAS was similar in the stromal tissue in various groups but in stromal blood vessels it varied among the groups. Epithelium of various types of ducts the reaction for best carmine, Sudan black B and bromophenol blue was similar in all the groups but the reaction for acid muccopolysaccharides and PAS was different in various groups. All the cells of islets exhibited mild to moderate PAS positive reaction. The islets cells showed mild positive reaction for best carmine. The reaction for acid muccopolysaccharides was negative in the islets cells. The islets cells showed moderate positive reaction for bromophenol blue. Mild positive reaction for Sudan black B was found in the islets of Langerhans in all the groups.

\section{Introduction}

Pancreas is an important mixed gland associated with the gastrointestinal tract. It lies on the right side of the abdominal cavity in all birds and is considered as the largest gland attached with the alimentary tract (Mobini, 2013 in pigeon and Deprem et al., 2015 in goose). The exocrine function of pancreas is the production and secretion of fluids which help in digestion (Ensmiger, 1992). Duodenum receives digestive enzymes and bicarbonate from the pancreas. The bicarbonates counter the effect of hydrochloric acid from the proventriculus and increase the $\mathrm{pH}$ of intestinal contents of the later half of duodenum from strongly to weakly acidic; hence, it protects the intestinal mucosa. The endocrine part of pancreas (islets of langerhans) contains alpha and beta cells located in separate islets in domestic animals (Getty, 1969). The beta or B cells of pancreatic islets secrete insulin that functions to increase glucose uptake by muscles, liver and adipose tissue and also enhances the lipogenesis. The pancreatic islet alpha or A cells secrete glucagon which causes lipolysis in adipose tissue, decrease in muscles and liver glycogen, decrease in glucose utilization, increase in gluconeogenesis and decrease in 
lipogenesis (Scanes, 2011). Hence, Insulin and glucagon play critical role in glucose homeostasis and serve as acute regulators of blood glucose level.

\section{Materials and Methods}

The present study was conducted on the pancreas of thirty apparently healthy Chabro birds irrespective of the sex. The birds were procured from University poultry farm of DUVASU. Six birds from each group were sacrificed at $0,30,60,90$ and 150 days after hatching. The pancreas of each bird was fixed in $10 \%$ neutral buffered formalin for histochemical studies. Fixed tissues were processed by routine paraffin embedding technique (Luna, 1968). The paraffin sections of $5 \mu$ were obtained for different histochemical studies. The sections were stained by periodic acid-Schiff's (PAS) method for demonstration of polysaccharides, Muller's colloidal (hydrous) ferric oxide method for demonstration of acid mucopolysaccharides, Sudan black-B method for demonstration of bound lipids, Bromophenol blue for demonstration of protein (Luna, 1968).

\section{Results and Discussion}

The reaction in stroma and stromal blood vessels was mild to moderate for best carmine, moderate for bromophenol blue and Sudan black B. The stromal blood vessels showed moderate reaction for acid mucopolysaccharides. The reaction for PAS was similar in all component of stromal tissue of various groups except in stromal blood vessels where it varied among the groups; in stromal blood vessels it was moderate to intense in group 1 and group 2 and intense in group 3 and group 4 but other stromal components showed mild to moderate reaction for PAS.
In the epithelium of all types of ducts Best carmine, Sudan black B and bromophenol blue showed similar reaction among the groups but the reaction for acid mucopolysaccharides and PAS was different in various groups.

The cytoplasm of acinar cells and cytoplasmic granules exhibited mild to moderate and intense reaction for PAS, respectively. Jain (2009) reported that PAS activity was moderate in chicks of CARI Shyama, mild to moderate in chicks of Vanaraja, moderate in growers of CARI Shyama, intense in growers of Vanaraja and mild to moderate in pullets of both breeds. Hamodi et al., (2013) stated that the pancreatic acinar cells were moderately positive for PAS in Common gull and Guinea fowl. However, according to Vaish (2005) in Kadaknath fowl negative reaction for PAS was observed in all the structures of pancreas. In group - 1 and group- 2 of present study the cytoplasm of the epithelial cells of various ducts was moderate to intensely PAS positive but in group- 3 and group- 4 intense PAS positive reaction was observed. According to Sivakumar et al., (2000) the lining epithelium of all the ducts was PAS-positive in Japanese quail. Kadhim et al., (2010) in red jungle fowl noticed the ductal epithelium has apical secretory granule which appeared PAS positive. Dprem et al., (2015) observed positive reactions for PAS in duct epithelium of goose. The secretory products of various ducts in the pancreas of chabro chicken was intensely positive for PAS. Dprem et al., (2015) found PAS-positive substance in the secretory material of duct lumen in goose.

The cytoplasm of acinar cells in the pancreas of chabro chicken showed mild positive reaction for Best carmine but the cytoplasmic granules of these cells were negative for this substance. The epithelial cell cytoplasm and the lumen material in the various ducts exhibited mild to moderate and mild reaction 
for best carmine, respectively. Conklin (1974) reported the presence of glycogen in pancreatic ducts. In the pancreas of chabro chicken mild positive reaction for bromophenol blue was observed in the cytoplasm of acinar cells. The reaction for this substance in cytoplasmic granules was intense. The cell cytoplasm of the lining epithelium of various ducts and their lumen material was moderate and intensely positive for bromophenol blue, respectively. Hamodi et al., (2013) stated that the pancreatic cells in common gull and guinea fowl showed moderate to weak negative reaction with $\mathrm{PB}$ stain for the proteins (Fig. 1-4).

Fig. 1 Photomicrograph of ventral lobe of pancreas in 150 days old chabro chicken showing moderate to intense reaction for bound lipids in secretory material of duct (a) and moderate to intense reaction in acinar cells (b). Acetone Sudan Black Stain; X400

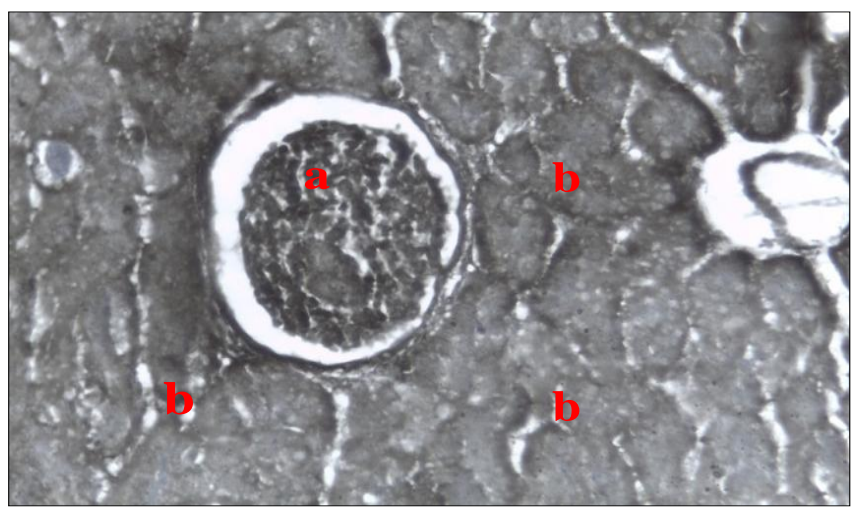

Fig.2 Photomicrograph of dorsal lobe of pancreas in 150 days old chabro chicken showing intense acid mucopolysaccharids reaction in the epithelium of large interlobular duct and moderate reaction in the wall of duct (a) Modification of Mowry's (1958) Colloidal Iron Stain Acid Mucopolysaccharids; X400

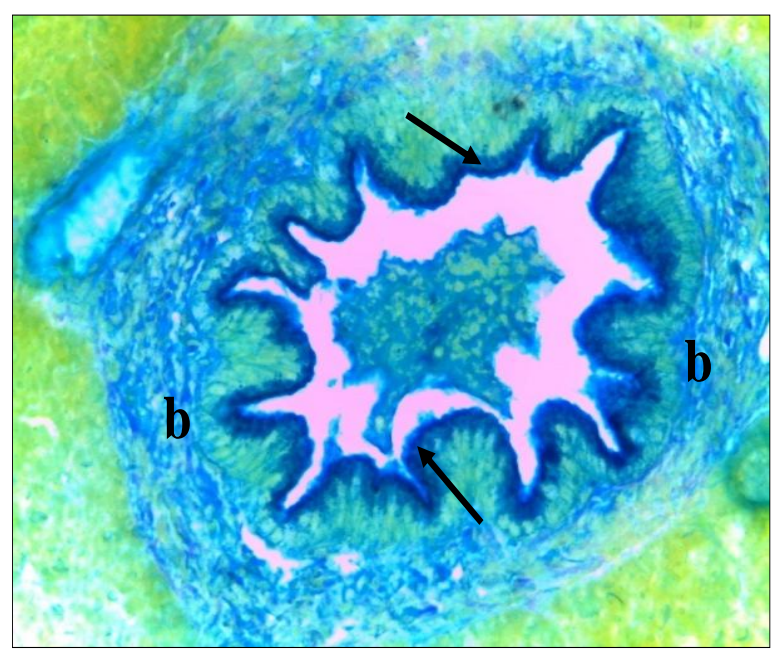


Fig.3 Photomicrograph of ventral lobe of pancreas in 30 days old chabro chicken showing moderate Bromophenol blue reaction in epithelium of intra lobular duct (a), intense reaction in cytoplasmic granules (b) and intense reaction in secretory materials of the duct (c). Mercury Bromophenol Blue Stain; X200

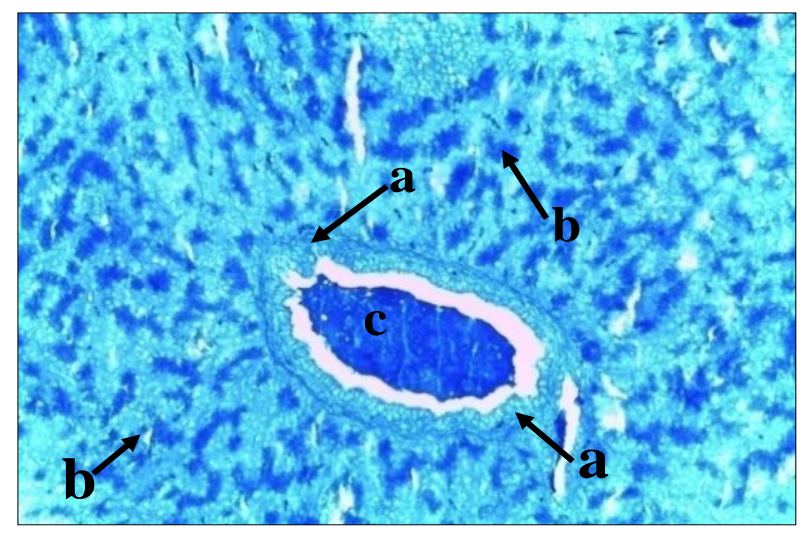

Fig.4 Photomicrograph of splenic lobe of pancreas in 0 day old chabro chicken showing intense PAS reaction in cytoplasmic granules (a) and mild to moderate reaction in cytoplasm of acinar cells (b). Periodic Acid Schiff's Stain; X200

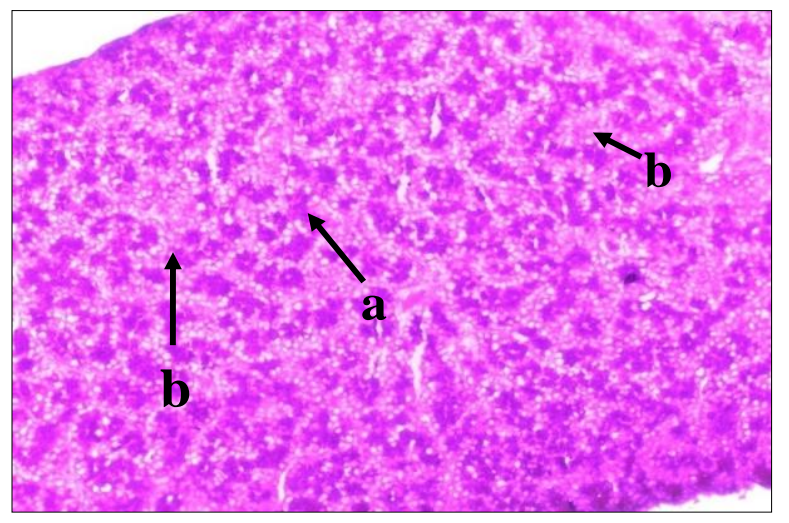

The cytoplasm of acinar cells showed mildly positive reaction for acid mucopolysaccharides, whereas, the cytoplasmic granules of these cells were negative for these substances. The secretory material in the lumen of various types of ducts was also negative for these substances. In ductual epithelium the reaction for acid mucopolysaccharides gradually increased with the increase in the age of the chicken. In the larger ducts of group- 1 moderate acid mucopolysaccharides were observed in the apical- border of larger ducts epithelium but smaller ducts the reaction was mild or absent. In group 2 the intense positive reaction for these substances was observed in the apical border of larger ducts but in smaller ducts the reaction was mild. In group 3 larger ducts showed intense positive reaction for acid mucopolysaccharides in apical border and upper part of the epithelial cells but in small ducts moderate to intense reaction was observed. The highest reaction for these substances was observed in group- 4 where all 
the epithelial cells of larger and smaller ducts were converted in to the globlet cells and these showed intense acid mucopolysaccharides. In ostrich, the surface epithelium of pancreatic ducts showed a thick coating of mucopolysacharides, the glycocalyx (Stornelli et al., 2006).

The acinar cells cytoplasm in the pancreas of chabro chicken exhibited moderate to intense positive reaction for bound lipids, whereas, faint reaction for these lipids was observed in cytoplasmic granules. The epithelial cell cytoplasm of various pancreatic ducts and the material in the lumen of ducts showed moderate to intense reaction for bound lipids. Hamodi et al., (2013) stated that the pancreatic cells of common gull and guinea fowl showed a negative reaction with SB stain for the lipids.

Similar findings for various histochemical reactions were also observed in the islets cells of various lobes. Both alpha and beta cells exhibited mild to moderate PAS positive reaction. Hamodi et al., (2013) stated that the islets cells were moderately positive for PAS in common gull and guinea fowl. The islets cells in chabro chicken showed mild positive reaction for Best carmine and negative reaction for acid mucopolysaccharides. These were moderately positive for bromophenol blue and mildly positive for Sudan black B. Hamodi et al., (2013) stated that the islets cells were negative with SB stain for lipids in common gull and guinea fowl.

\section{References}

Conklin, J.M. 1974. Cytogenesis of the Human Fetal Pancreas. American Journal of Anatomy, 111(2):181-196.

Deprem, T., Tasci S.K., Bingol, S.A., Sari, E.K., Aslan, S. and Ilhan, S. 2015. Histological and histochemical studies on the structure of pancreatic ducts of goose. Turkish journal of Veterinary Animal Science, 39:62-68.

Ensminger, M.E. 1992. Poultry Science (3rd ed.) Interstate Publishers, INC. Danville, Illinois, USA.

Getty, R. 1975. The anatomy of the domestic animals. Fifth edition. W.B. saunders company Philadelphia. Pp. 1876-1878.

Hamodi, H.M., Abed, A.A. and Ameer, M.T. 2013. Comparative anatomical, histological and histochemical study of the pancreas in two species of birds. Research and reviews in Bioscience, 8(1): $26-34$.

Jain, P. 2009. Gross, histomorphological and histochemical studies on intestine, pancreas and bursa of fabricius of cari shayam and vanaraja breeds of poultry, M.V.Sc. Thesis, Indira Gandhi Krishi Vishwavidalaya, Raipur, pp 64.

Kadhim, K.K., Zuki, A.B., Noordin, M. M., Babjee, S.M. and Zamri, S.M. 2010. Morphological Study of pancreatic duct in red Jungle fowl. African Journal Biotechnology, 9: 7209-7215.

Luna, L.G. 1968. Manual of Histological Staining Methods of the Armed Forces Institute of pathology. $3^{\text {rd }} \mathrm{Ed}$, McGraw Hill Book Company, New York, USA

Mobini, B. 2013. Histochemical and histological studies on the pancreas in mature pigeon (Columba Livia). European Journal of Experimental Biology, 3: 148-152.

Scanes, C.G. 2011. Hormones and Metabolism in Poultry. In: Scanes C.G. Update on Mechanisms of Hormone Action - Focus on Metabolism, Growth and Reproduction. Publisher In Tech., pp 111-132.

Sivakumar, M. Kannan, T.A. Parida, S.N. Sathyamoorth, O.R. and Vijayaragavan, C. 2000. Histology and histochemistry of the ductular and 
stromal components of the post hatch exocrine pancreas of Japanese quail (Coturnix coturnix japonica). Journal of Veterinary and Animal Sciences, 31: 44-46.

Stornelli, M. R., Ricciardi, M.P., Miragliotta, V., Coli, A., and Giannessi, E., 2006. Morpho-structural Study of the Pancreas and Pancreatic Duct in
Ostrich (Struthio camelus L.). Acta Veterinaria Brunensis, 75(2): 157-160.

Vaish, M.K. 2005. Pre and post hatch developmental studies on digestive system of Kadaknath fowl. M.V.Sc. Thesis, Jawaharlal Nehru Krishi Vishwavidyalaya, Jabalpur, pp. 25-58.

\section{How to cite this article:}

Renu Yadav, Ajay Prakash, M.M. Farooqui, Archana Pathak and Amit Vishen. 2020. Histochemical Studies in Exocrine and Endocrine Part of Pancreas in Chabero Chicken. Int.J.Curr.Microbiol.App.Sci. 9(09): 1091-1096. doi: https://doi.org/10.20546/ijcmas.2020.909.136 